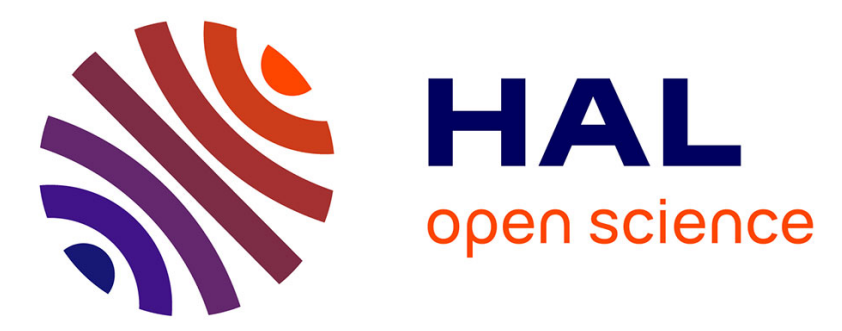

\title{
245 - A highly sensitive glucose electrode using glucose oxidase collagen film
}

Daniel R. Thevenot, Robert Sternberg, Pierre R Coulet, Danièle C Gautheron

\section{To cite this version:}

Daniel R. Thevenot, Robert Sternberg, Pierre R Coulet, Danièle C Gautheron. 245 - A highly sensitive glucose electrode using glucose oxidase collagen film. Bioelectrochemistry and Bioenergetics, 1978, 5, pp.548 - 553. 10.1016/0302-4598(87)85047-X . hal-01083001

\section{HAL Id: hal-01083001 \\ https: / hal-enpc.archives-ouvertes.fr/hal-01083001}

Submitted on 14 Nov 2014

HAL is a multi-disciplinary open access archive for the deposit and dissemination of scientific research documents, whether they are published or not. The documents may come from teaching and research institutions in France or abroad, or from public or private research centers.
L'archive ouverte pluridisciplinaire HAL, est destinée au dépôt et à la diffusion de documents scientifiques de niveau recherche, publiés ou non, émanant des établissements d'enseignement et de recherche français ou étrangers, des laboratoires publics ou privés.

\section{(c)(1)}

Distributed under a Creative Commons Attribution| 4.0 International License 


\title{
245 - A Highly Sensitive Glucose Electrode Using Glucose Oxidase Collagen Film *
}

\author{
by Daniel R. Thevenot $0 \cdot{ }^{*}$ Pierre R. Coulet ${ }^{\circ}$, \\ Robert Sternberg ${ }^{\circ}$ and Daniele C. Gautheron 00
}

- Equjpe de Biólectrochimie et d'Analyse du Milieu, Laboratoire d'Energétique Biochimique, Université Paris Val de Marne, Avenue du Général de Gaulle, 940ro Créteil Cédex, (France)

oo Laboratoire de Biologie et de Technologie des Membranes, CNRS - Université Claude Bernard, 43, Boulevard du xi Novembre Igr8, 69621 Villeurbanne Cédex, (France)

Manuscript received April $7^{\text {th }}$ r 978

\section{Summary}

Industrially recorstituted collagen films have shown excellent properties for $\beta-D$-glucose oxidase couplirg. Associated with a platinum anode for amperometric detection of hydrogen peroxide, these er zymatic films form a very simple and easy to handle glucose electrode ; this device presents a very high ser sitivity (ca. Io ${ }^{-8} M$ ) givir g resporses proportioral to glucose concentration over 5 orders of magritude.

\section{Introduction}

The association of an er zyme in a soluble form with an electrochemical ser sor was first reported by CLARK and LyoNS, in I962." Since this date, the obtainment of carrier-bound erzymes has permitted the design of er zyme electrodes. In most cases, erzymes are trapped in gels surroundirg the sersor ${ }^{2}$ leadirg to systems which are difficult to handle.

In the present work, an er zymatic membrane was prepared from reconstituted calf skin collagen after acyl-azide activation and a couplirg process giving a surface bindirg of er zymes of different classes. ${ }^{3-5}$ A glucose electrode usirg $\beta$ - $D$-glucose oxidase (GOD) membrares was developed, usirg an amperometric method with a platirum electrode to detect hydrogen peroxide, which is a product of the el zymatic oxidation of glucose according to the reaction :

$$
\beta-D \text {-glucose }+\mathrm{O}_{2} \stackrel{\text { GOD }}{\longrightarrow} \text { gluconic acid }+\mathrm{H}_{2} \mathrm{O}_{2}
$$

* Discussed at the $4^{\text {th }}$ International Symposium on Bioelectrochemistry, Woods Hole (Mass.), 2-8 October 1977.

- To whom all correspondance should be addressed. 
The potential was fixed at $+650 \mathrm{mV}$ vs $\mathrm{Ag} \mid \mathrm{AgCl}, \mathrm{KCl}$ o.I $M$ and the anodic current was recorded. A stationary response was then obtained allowing the measurement of very low glucose concentrations. In a more sophisticated device, a second electrode involving a non-enzymatic membrane was used to compensate for the detection of other electroactive molecules and to enhance the selectivity of the glucose electrode. ${ }^{6,7}$

\section{Experimental}

\section{Instrumentation}

The glucose electrode consisted of a modified gas electrode in which the $\mathrm{pH}$ detector was replaced by a platinum disk and the usual teflon film by a collagen membrane. In a differential device, electrode I was mounted with a $\beta-D$-glucose oxidase collagen membrane and electrode 2 with a non-erzymatic one.

Electronics were made by Solea TACUSSEL : current outputs of both working electrodes were first subtracted (Deltapol) and then twice differenciated (Derivol) with a time-base of one second (GSTP); thus different current vs time curves were avaliable and usually recorded after a glucose pulse (SoleA TACussel EPL 2 with TV II GD plug-in unit, and three traces LINEAR 395 recorders).

Unless otherwise mentioned, the temperature of the solutions were carefully thermostated to $30.0 \pm 0 .{ }^{\circ} \mathrm{C}$ (Colora cryothermostat WK 5 DS).

\section{Solutions and reagents}

Insoluble films of highly polymerized reconstituted collagen (20 cm wide) were a gift of the Centre Technique du Cuir, Lyon (France) ; their thickness is about $0.1 \mathrm{~mm}$ in a dry state and $0.3-0.5 \mathrm{~mm}$ when swollen. They do not need to be tanned and can be stored several years without damage. ${ }^{3-5}$

Unless otherwise mentioned, all chemicals were reagent grade. The stock solutions of $0.1 M$ glucose were allowed to mutarotate at room temperature at least 3 hours before using and were stored at $4^{\circ} \mathrm{C}$. Both electrodes were filled with and dipped into $0.2 M$ acetate buffer, 0. I $M \mathrm{KCl}$ solutions, $\mathrm{pH} 5.6$.

\section{Glucose oxidase binding on collagen membranes}

The mild general acyl azide procedure for collagen membranes activation was used ${ }^{3-4}$ followed by the enzyme coupling.

Carboxyls were first esterified by immersion of crude membranes in a methanol/0.2 $M$ hydrochloric acid solution for at least 72 hours, then treated overnight by $\mathrm{I} \%$ hydrazine and soaked at $4^{\circ} \mathrm{C}$ for $3 \mathrm{mi}$ nutes in $0.5 M \mathrm{NaNO}_{2}-0.3 \mathrm{M} \mathrm{HCl}$ mixture just before coupling. Thorough washings were performed between each step and at the end of the 
activation process avoiding contact between reagents and enzyme solutions.

Activated films of $2 \times 1.5 \mathrm{~cm}^{2}$ were dipped ( 2 hours at $4^{\circ} \mathrm{C}$ ) into I. $5 \mathrm{~cm}^{3}$ of borate buffer at $\mathrm{pH} 9$ containing $2.5 \mathrm{mg} \beta-D$-glucose oxydase (GOD, E.C. I.I.3.4, BOEHRINGER lyophilizate, grade I). Excess of soluble glucose oxidase was washed away for about roo minutes in I $M \mathrm{KCl}$ and surface activity was in the range $30-60 \mathrm{nmol} . \mathrm{min}^{-1} \mathrm{~cm}^{-2}$. Erzyme collagen membranes were stored in $0.2 \mathrm{M}$ acetate buffer, $0.1 \mathrm{M} \mathrm{KCl}$ ( $\mathrm{pH}$ 5.6).

\section{Procedure}

Both electrodes were allowed to equilibrate in the buffer solution for 15 to 30 minutes after stepping the potential of the platinum disks to $+650 \mathrm{mV}$ vs $\mathrm{Ag} \mid \mathrm{AgCl}$, o.I $M \mathrm{KCl}$. This potential corresponds to a diffusion-limited current for $\mathrm{H}_{2} \mathrm{O}_{2}$ oxidation. Calibrations were performed by successive microadditions (Io to $50 \mathrm{~mm}^{3}$ ) of stock solutions of $1 \mathrm{IO}^{-6}$ to $\mathrm{IO}^{-1} M$ glucose to Io to $20 \mathrm{~cm}^{9}$ of buffer. The stationary response was the variation of the steady state values of $I_{1}-I_{2}$ when a sample of a glucose containing solution was added and the dynamic response was the height of the peak of the first derivative $d\left(I_{1}-I_{2}\right) / \mathrm{d} t$. When successive additions were performed in the same solution, a current offset was used.

\section{Results and discussion}

When the enzyme electrode is immersed in a medium in which a pulse of glucose is added a steady state takes place after 2-3 minutes, as shown on Fig. I, and the value of the anodic current reaches a plateau. The variation of intensity is directly dependent on the glucose concentration in the assay: this is the stationary response. On the other hand, the dynamic response is measured by the height of the peak obtained after $30-50 \mathrm{~s}$ by recording the first derivative of this current.

The lowest glucose concentration detected under these conditions is less than $10^{-8} M$ (Fig. 2). For values higher than $\mathrm{IO}^{-2} M$, the responses become independent of the glucose concentration. The concentrations, which can be determined, range between $c a . \mathrm{IO}^{-8}$ and $\mathrm{IO}^{-2} M$ i.e. over 6 orders of magnitude and the linearity of the calibration curye is obtained between $(3-5) \times \mathrm{IO}^{-8}$ and $(3-5) \times \mathrm{IO}^{-3} \mathrm{M}$ i.e. over 5 orders of magnitude (Fig. 2).

In a typical experiment, the calibration curves remained linear even after 40 hours operation at $30^{\circ} \mathrm{C}$ and 250 days storage at $4^{\circ} \mathrm{C}$, allowing accurate repeated determinations for I60 micro-assays tested. However, a daily calibration was necessary, because of the slight decreasing of the calibration curve slope: $c a .20 \%$ after 20 hours operation (cumulated time of measurements) and $20-50 \%$ after 40 hours. The accuracy of glucose determinations during a set of experiments was tested by successive additions of the same aliquot of glucose (Fig. I); 


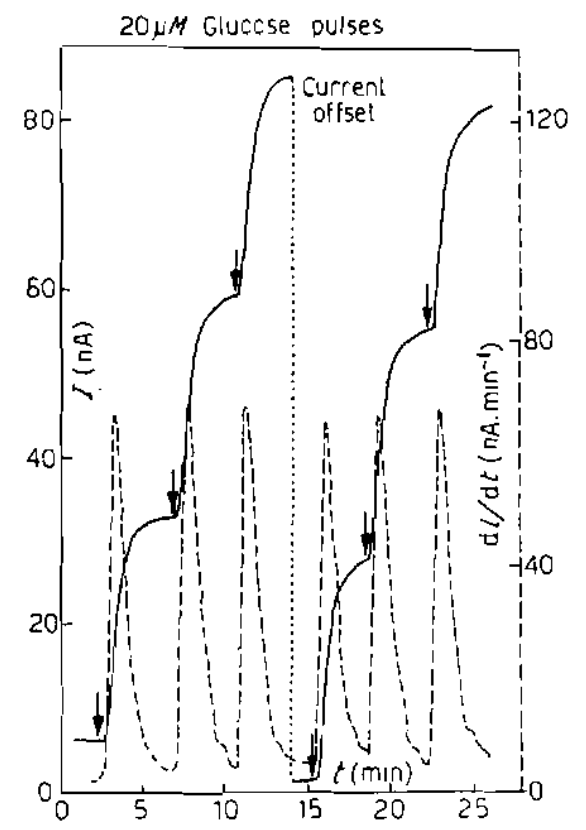

Fig. 1.

Electrode responses when successive zo $\mu M$ glucose pulses are added to the buffer solution. Addition of $40 \mathrm{~mm}^{3}(\mu \mathrm{l})$ aliquots of ro $\mathrm{mM}$ glucose solution into $20 \mathrm{~cm}^{9}$ of $0.2 M$ acetate buffer, o.I $M \mathrm{KCl}$ (pH 5.6) solution. (- $\longrightarrow$ direct current giviug stationary responses, $(--\rightarrow$ first derivative of this current giving dynamic responses.

Fig. 2.

Calibration curves of the glucose electrode. ( - - ) stationary response ; $(--\longrightarrow$ dynamic response.

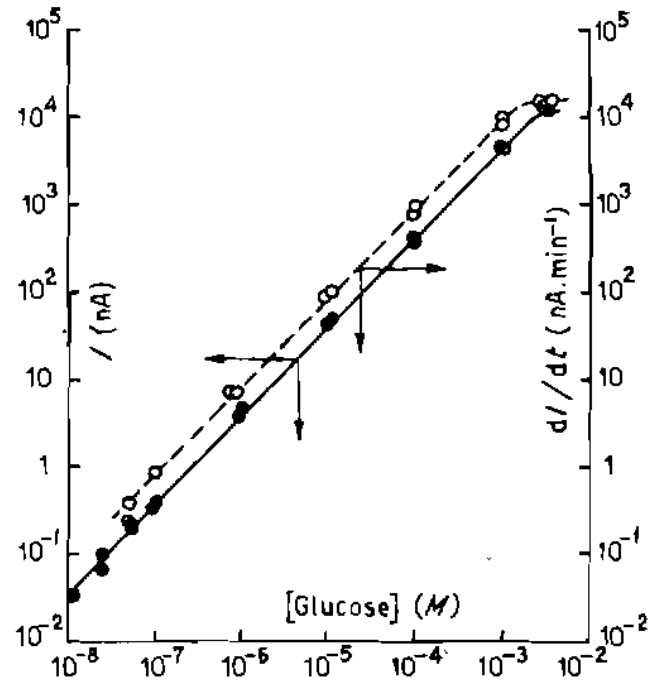

for $\mathrm{I}_{3}$ successive additior s of $\mathrm{IO}^{-5} M$ glucose, the standard deviation from the mean is usually lower than $2 \%$.

Glucose oxidase itself is very selective for $\beta-D$-glucose; thus enzymatic electrode I presents a high selectivity for glucose compared 
with usual sugars : selectivity ratios are higher than 2 ooo / I for fructose, lactose and sucrose. As other species may diffuse through collagen membranes and may be oxidized on platinum at +o.94 V (N.H.E.), the use of a compensating non enzymatic electrode 2 eliminates possible interferences of species such as ascorbate, urate, tyrosine or hydrogen peroxide; the selectivity ratio for hydrogen peroxide ranges between $80 / \mathrm{I}$ and $250 / \mathrm{I}$ depending upon experimental parameters (accuracy of the balance of both electrodes and GOD activity of the film).

The use of nou-enzymatic electrode 2 is specifically of greatest interest for blood glycemia determinations, $I_{2}$ usually reaching ro-50\% of $I_{1}-I_{2}$. Fig. 3 presents the typical analysis of blood plasma samples after induced glycemia : in this case, a glucose calibration is necessary for each set of 3-4 blood additions. The dotted line, representing the second derivative of the current $I_{1}-I_{2}$, has been successfully used for monitoring a printing device of the peak of the first derivative, i.e. the dynamic response. ${ }^{7}$

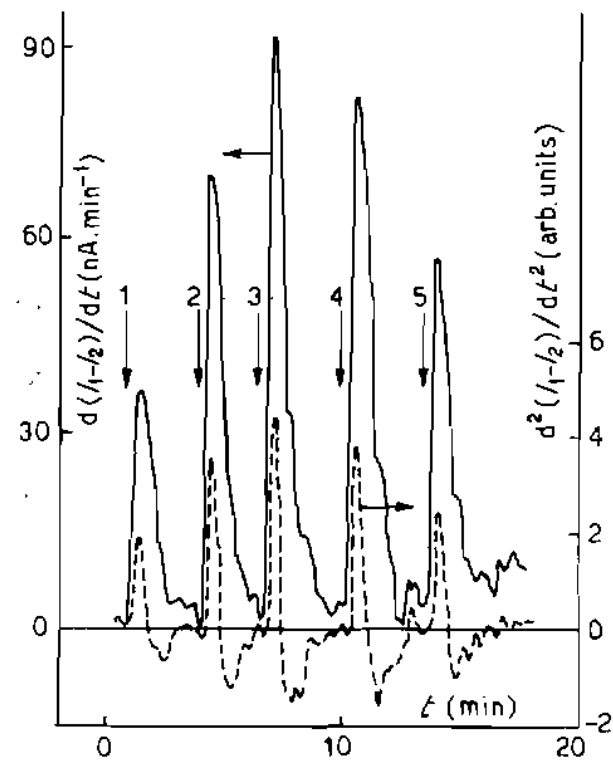

Fig. 3.

Induced glycemia. (- $(\longrightarrow)$ first and $(-\longrightarrow)$ second derivative of the current after injection of $50 \mathrm{~mm}^{\mathrm{s}}$ ( $\mu$ l) non deproteinized plasma samples. to $20 \mathrm{~cm}^{3}$ buffer ( $\mathrm{I}$ ) calibration of the electrode with a ro $\mu M$ glucose pulse, (2-5) glncose determination in plasma samples taken after o (2), 30 (3), 6o (4) and 120 minutes (5) after indnced glycemia. Corresponding glncose content were respectively r. I, I.7, I.4 and $\mathrm{I} .0 \mathrm{~g} / \mathrm{l}$.

The glucose electrode may be used in a large temperature range, from I5 to $40^{\circ} \mathrm{C}$. As both responses are very sensitive to temperature (about $4-5 \% /{ }^{\circ} \mathrm{C}$ at $30^{\circ} \mathrm{C}$ ) it is necessary to carefully thermostate the solutions in contact with both electrodes. 


\section{Conclusions}

Industrially reconstituted collageu films were found suitable for glucose oxidase immobilization; the enzymatic activity was maintained and its stability enhanced. A membrane loading of 50 to $100 \mathrm{mU}$ per membrane ( $\mathrm{c} \mathrm{cm}$ diameter) was sufficient to obtain a very sensitive glucose electrode when associated with amperometric hydrogen peroxide detection. Stationary and dynamic responses of this glucose electrode was proportionnal to glucose concentration from $3-5 \times \mathbf{r o}^{-8}$ to $3-5 \times$ $\mathrm{I}^{-3} M$. Furthermore, this sensor was used for whole blood samples analysis in induced glycemia.

\section{Acknowledgements}

This work was partially supported by the Délégation Générale à la Recherche Scientifique et Technique, grant $n^{\circ} 76.7 .0920$.

\section{References}

1 L.C. Clak and C. Lyons, Ann. N.Y. Acad. Sci. 102, 29 (1962)

2 G.G. Grilbault, in Immobilized Enzymes, Antigens, Antibodies and Peptides, H.H. Weerall (Editor), Marcel Dekker Inc., New York (1975) p. 293

3 P.R. Coulet, J.H. Julliard, D.C. Gautheron, Brevet d'Invention Français (ANVAR) $\mathrm{n}^{0}$ 2.235.133 (1973)

* P.R. Coulet, J. H. Julliard and D.C. Gautheron, Biotechnol. Bioeng. 16, I055 (1974)

5 P.R. Coulet and D.C. Gautheron, in Analysis and Control of Immobilized Enzyme Systems, D. Thomas and J.P. Kernevez (Editors), North Holland, Amsterdam (1976) p. I65

8 D.R. Thevenot, P.R. Coulet and D.C. Gautheron, in Enzime Engineering Plenum Press, New Yorl (1978) Vol. 4, p. 221

7 D.R. Theyenot, P.R. Coulet, R. Sterneerg, J. Laurent and D.G. GauTHERON to be published 